\title{
Morphological development of Anchoviella vaillanti (Steindachner, 1908) (Clupeiformes: Engraulidae) larvae and early juveniles
}

\author{
Anailza Cristina G. da Silva ${ }^{1}$, William Severi ${ }^{1}$ and Maviael F. de Castro ${ }^{2}$
}

The considerable similarity in the early life stages of different fish species makes egg and larvae identification in fishery biology and ichthyoplankton surveys a difficult task. Knowledge on early larval development of morphologically similar taxa and species-rich orders, such as Clupeiformes, mainly in the Neotropical fresh waters is rather limited. The aim of the present study was to describe morphological and meristic aspects of the larvae and early juveniles of Anchoviella vaillanti, an endemic species of the São Francisco River basin in Brazil. The characterization was based on an ontogenetic series of 132 individuals (1.3-51.0 mm SL). In the larval period, body varies from elongated to very elongated and the head is small, which is typical of Clupeiformes. The finfold is present beginning in the yolk-sac stage, when larvae have a large yolk sac, until the flexion stage. Pectoral fin buds are the first to form during the preflexion stage, when dorsal- and anal-fin pterygiophores and hypural bones are first visible. The total vertebra count ranges from 36 to 39 and the myomere number ranges from 31 to 45 . Complete fin formation obeys the following sequence: anal and dorsal fins during flexion stage; and pectoral, pelvic and caudal fins during postflexion stage. Despite being the only freshwater clupeiform representative in the São Francisco River, A. vaillanti may occur sympatrically with A. lepidentostole in the lower stretches of the river basin. Although early larvae characteristics of $A$. lepidentostole are not known, its late larvae and early juveniles may be distinguished from those of A. vaillanti, by the higher number of dorsal-fin rays ( 15 or $16 \mathrm{vs} .12$ or 13 in $A$. vaillanti), higher total vertebra count (40 vs. 37 to 40 ) and shorter pre-pectoral length (14 to $16 v s .22 .8$ to $28.9 \%$ SL).

A grande semelhança entre larvas de diferentes espécies de peixes torna a identificação de ovos e larvas em estudos de biologia pesqueira e ecologia do ictioplâncton uma tarefa difícil. O conhecimento sobre o desenvolvimento inicial de táxons com grande similaridade morfológica no período larval e riqueza taxonômica, como Clupeiformes, em particular daqueles de água doce na região neotropical, é bastante limitado. Neste sentido, o presente trabalho contribui para a redução desta lacuna, através da descrição morfológica e merística de larvas e juvenis iniciais de Anchoviella vaillanti, espécie endêmica da bacia do rio São Francisco. A caracterização foi realizada a partir de uma série ontogênica de 132 indivíduos (1,3-51,0 mm CP). No período larval, o corpo varia de muito alongado a alongado e a cabeça é pequena, características de Clupeiformes. A nadadeira embrionária está presente desde o estágio larval vitelino, no qual as larvas apresentam um saco vitelino grande, até o estágio de flexão. Os botões das nadadeiras peitorais são os primeiros a surgir, no estágio de pré-flexão, quando surgem também os pterigióforos das nadadeiras dorsal, anal e os ossos hipurais. O número total de vértebras varia de 36 a 39 e de miômeros de 31 a 45; a completa formação das nadadeiras obedece à seguinte ordem: anal e dorsal no estágio de flexão; e peitoral, pélvica e caudal no estágio de pós-flexão. Embora seja o único engraulídeo de água doce da bacia do rio São Francisco, $A$. vaillanti pode ocorrer simpatricamente com $A$. lepidentostole no trecho inferior da bacia. Embora as características de larvas iniciais de $A$. lepidentostole não sejam conhecidas, seus estágios larvais finais e juvenis podem ser distinguidos daqueles de $A$. vaillanti pelo maior número de raios da nadadeira dorsal (15 ou 16 vs. $12 \mathrm{ou} 13 \mathrm{em}$ A. vaillanti), maior número total de vértebras (40 vs. 37 a 40) e menor comprimento pré-peitoral ( 14 a 16 vs. 22,8 a 28,9\% CP).

Key words: Anchovy, Ontogeny, São Francisco River, Brazil.

\footnotetext{
${ }^{1}$ Laboratório de Ictiologia, Departamento de Pesca e Aquicultura - UFRPE. Rua Dom Manoel de Medeiros, s/n, Dois Irmãos, 52171-900 Recife, PE, Brazil. wseveri@depaq.ufrpe.br (corresponding author) ${ }^{2}$ Instituto Agronômico de Pernambuco, Recife, Pernambuco, Brazil.
} 


\section{Introduction}

Studies on the ontogeny of fish in the Neotropical freshwater environments are geographically dispersed in the region (Nakatani et al., 2001). In Brazil, important contributions have been made by Araújo-Lima $(1985,1991)$, Araújo-Lima et al. (1993) and Oliveira et al. (2008) for the Amazon region; Cavicchioli et al. (1997), Nakatani et al. (1997), Bialetzki et al. (1998, 2001, 2008) and Sanches et al. $(1999,2001)$ for the upper Paraná River; Sousa \& Severi (2002) and Severi \& Verani (2006) for the Paraguay River; and Godinho et al. (2003) and Sampaio (2006) for the São Francisco River. These studies are mostly on Characiformes and Siluriformes and there is limited knowledge on the remaining 23 orders occurring in the Neotropics (Reis et al., 2003), including the 35 known clupeiform species distributed among Clupeidae, Engraulidae and Pristigasteridae.

There are six genera of Engraulidae in the Neotropical region. Anchoviella has eleven species (Kullander \& Ferraris, 2003), five of which are freshwater species. Anchoviella vaillanti (Steindachner, 1908) is the only clupeiform representative in the São Francisco basin, where it is endemic. The species plays an important role in the food chain of aquatic environments in the basin as a key species in energy transfer from zooplankton to fish (Pompeu \& Godinho, 2003) and as a foraging species for piscivores (Peret, 2004; Rocha, 2009).

The greatest difficulty in the identification of the early developmental stages of Clupeiformes is the similarity in the external morphology of the larvae. Moreover, there is a lack of studies in the literature and species identification keys. Available descriptions are very incomplete (McGowan $\&$ Berry, 1984) and mostly for marine species (e.g., Richards, 2006). Meristic characters overlap among species, as shown for Neotropical freshwater clupeiforms (Table 1). Despite the ecological (as foraging species for a number of carnivores) and economic importance of exclusively freshwater Neotropical clupeiforms (Whitehead, 1985, 1988; Leis \& Trnski, 1989; Kullander \& Ferraris, 2003), larval development has only been described for Pellona flavipinnis (Valenciennes) (Severi \& Verani, 2006).

The ontogeny of sardines and anchovies is better known for commercially important species in regions with low species richness (McGowan \& Berry, 1984), such as the Northeast Atlantic (e.g., Engraulis, Clupea, Sardina, Sparattus), and there is little detailed information on more species-rich areas, such as the Central Western Atlantic (Farooqi et al., 2006). Among the 28 engraulid species recorded for this area, only two have their larval development properly characterized.

As knowledge on Neotropical freshwater clupeiform larval development is limited (Severi \& Verani, 2006), the aim of the present paper is to describe morphological aspects of the larvae and early juveniles of the engraulid A. vaillanti and help in species identification in ichthyoplankton surveys in the São Francisco basin.

\section{Material and Methods}

The material used in this study was obtained from surface tows with a $0.5 \mathrm{~mm}$ mesh conical-cylindrical

Table 1. Meristic data of exclusively freshwater neotropical clupeiform species (\#euryhaline marine species).

\begin{tabular}{|c|c|c|c|c|c|c|c|}
\hline \multirow{2}{*}{ Species } & \multicolumn{4}{|c|}{ Fin rays } & \multirow{2}{*}{ Vertebrae } & \multirow{2}{*}{ Scutes } & \multirow{2}{*}{ References } \\
\hline & dorsal & pectoral & pelvic & anal & & & \\
\hline \multicolumn{8}{|l|}{$\begin{array}{l}\text { PRISTIGASTERIDAE } \\
\end{array}$} \\
\hline Ilisha amazonica & $20 *$ & & $6^{*}$ & $47-52$ & $50-52 *$ & $25-26$ & Whitehead (1985); *McGowan \& Berry (1984) \\
\hline Pellona castelnaeana & iii 15 & i 15 & i 6 & iii $31-35$ & $45-46$ & $33-34$ & Whitehead $(1973,1985)$ \\
\hline Pellona flavipinnis & iii-iv $14-17$ & i $14-15$ & i 6 & iii-iv $35-41$ & $42(40-45)$ & $32-38$ & Whitehead $(1973,1985)$ \\
\hline Pristigaster cayana & iii $12-13$ & i $10-12$ & & ii-iii 44-53 & $43(42-44)$ & $30-35$ & Menezes \& de Pinna (2000) \\
\hline Pristigaster whiteheadi & iii $11-13$ & i $10-11$ & i 3 i & ii-iii 41-47 & $43-44$ & $29-34$ & Menezes \& de Pinna (2000) \\
\hline \multicolumn{8}{|l|}{ ENGRAULIDAE } \\
\hline Amazonsprattus scintilla & & & & iii $26-30$ & & & Whitehead et al. (1988) \\
\hline Anchovia surinamensis & $13-15$ & $13(12-14)$ & & $26-27(23-28)$ & $38-39$ & & Richards (2006) \\
\hline Anchoviella alleni & & & & iii $15-18$ & & & Whitehead et al. (1988) \\
\hline Anchoviella carrikeri & & & & iii $15-18$ & & & Whitehead et al. (1988) \\
\hline Anchoviella guianensis & $14-15(16)$ & $12-14$ & & $18-19(17-21)$ & $39-40$ & & Richards (2006) \\
\hline Anchoviella jamesi & $12-13 *$ & & & iii $16-21$ & $40^{*}$ & & Whitehead et al. (1988); *McGowan \& Berry (1984) \\
\hline Anchoviella lepidentostole\# & iii $12-13$ & i $12-13$ & i 6 & iii $19-22$ & $40 *$ & & Whitehead (1973); *Richards (2006) \\
\hline Anchoviella vaillanti & ii-iii 10 & i $12 *$ & i $6^{*}$ & iii $19-22$ & $37-40$ & & Steindachner, 1908; *Whitehead (1970) \\
\hline Jurengraulis juruensis & & & & iii $20-22$ & $20+20 *$ & & Whitehead et al. (1988); *McGowan \& Berry (1984) \\
\hline Lycengraulis batesii & iii $12-13$ & i $14-15$ & i 6 & iii $24-27$ & $47 *$ & & Whitehead (1973); *McGowan \& Berry (1984) \\
\hline Pterengraulis atherinoides & $13-14$ & $13-15$ & 7 & $33(31-34)$ & (42) $43-45$ & & Richards (2006) \\
\hline \multicolumn{8}{|l|}{ CLUPEIDAE } \\
\hline Dorosoma anale & & & & $29-38$ & & & Whitehead (1985) \\
\hline Dorosoma cepedianum & & & & $25-36$ & & & Whitehead (1985) \\
\hline Dorosoma petenense & & & & $17-27$ & & & Whitehead (1985) \\
\hline Dorosoma chavesi & & & & $24-30$ & & & Whitehead (1985) \\
\hline Dorosoma smithi & & & & $22-29$ & & & Whitehead (1985) \\
\hline Ramnogaster melanostoma & $15-16$ & 13-14 & & & & & Whitehead (1985) \\
\hline Rhinosardinia amazonica & iii-iv $10-12$ & i-ii $10-12$ & i 7 & iii-iv $34-38$ & $38-39$ & & Whitehead (1973) \\
\hline Rhinosardinia bahiensis & & & & & 43 & & Whitehead (1985) \\
\hline
\end{tabular}


plankton net in quarterly samplings in different stretches of the Sobradinho reservoir from January 2002 to January 2004. The Sobradinho reservoir is located in the middle portion of the São Francisco River between the cities of Xique-Xique (1046'26.5'S 42 44'08.4'W) and Sobradinho (09'25'49.7'S 4049'37.4'W), both located in the State of Bahia, northeastern Brazil.

Larvae and juveniles of Anchoviella vaillanti were separated from other taxa collected based on common characteristics of Clupeiformes, such as long and slender body with numerous myomeres; a long, straight and partially striated gut; posterior anus, anal fin insertion just behind dorsal fin, preanal length corresponding to more than $2 / 3$ of total length and posteroanterior development of dorsal fin rays (McGowan \& Berry, 1984; Nakatani et al., 2001). Individuals were classified based on the developmental degree of the caudal fin and its support elements into larval [yolk-sac (YS), preflexion (PF), flexion (FL) and postflexion (PO) stages] and juvenile (JV) periods (Nakatani et al., 2001).

The following morphometrical characteristics were measured (Nakatani et al., 2001): standard length (SL), preanal length (PAL), prepelvic length (PPVL), prepectoral length (PPL), predorsal length (PDL), head length (HL), head depth (HD), eye diameter (ED) and body depth (BD). Body proportions for ED, HL and BD were classified based on the categories proposed by Leis \& Trnski (1989).

Based on the assumption of dorsal fin anteriad migration during larval metamorphosis recorded for several clupeiform species (McGowan \& Berry, 1984), the variations of PDL and PAL in relation to SL were analyzed, based on comparison of mean values of such relations for larval stages and juveniles, using one-way ANOVA followed by a posteriori Tukey test, with the program Statistica 8.0 (Statsoft, 2008).

Some specimens were cleaned and stained (Dingerkus \& Uhler, 1977) for evidence of internal structures, preanal, postanal and total vertebra count, pectoral (P), dorsal (D), pelvic (V), anal (A) and caudal (C) fin ray count, as well as the position of dorsal- and anal-fin insertions relative to the vertebra number. All material used is deposited at the
Ichthyology Laboratory of the Fisheries and Aquaculture Department of the Universidade Federal Rural de Pernambuco, Recife, Brazil.

\section{Results}

A total of 132 individuals in the yolk-sac, preflexion, flexion and postflexion larval stages and early juvenile period were analyzed (Table 2$)$. Yolk-sac larvae $(\mathrm{n}=12)$ have standard lengths between 1.3 and $2.2 \mathrm{~mm}$ (Fig. 1a). Body ranges from very elongate to elongate $(9.1-14.3 \%$ SL), with a small head (10.0-14.3\% SL) and large eyes $(33.3 \%$ HL; Table 2).

Larva mouth is not yet open (functional), with no visible exogenous feeding and a large, conspicuous yolk sac. Eyes are only visible based on tissue morphology and position, with no evidence of pigmentation. A single finfold extends from dorsal region behind the head and envelops the body down to the end portion of the yolk sac in the ventral region.

In the preflexion stage (Fig. 1b-c), standard length ranges from 2.7 to $6.9 \mathrm{~mm}(\mathrm{n}=30)$. Body ranges from very elongate to elongate $(6.3-10.0 \% \mathrm{SL})$, head is small (7.9$14.8 \% \mathrm{SL}$ ) with a completely pigmented eye, ranging from small to large $(16.7-40.0 \% \mathrm{HL})$. Total myomere count ranges from 31 to 45 (20-24 preanal and 7-25 postanal; Table 3 ). The notochord is not flexed yet. The mouth is open and functional, with presence of exogenous food in the gut. The finfold has undergone no significant difference. Pectoral fin buds begin to form and are visible as delicate finfolds without rays. The swimbladder is clearly visible above the gut, located in the mid-portion of the preanal length and initial formation of the opercle is evident. Larvae with SL between 3.3 and $4.0 \mathrm{~mm}$ exhibit punctiform chromatophores sparsely distributed above the gut and on the isthmus. Cleared and stained individuals with SL $>5 \mathrm{~mm}$ had clearly evident dorsal (49) and anal (4-15) fin pterygiophores and hypural bones (2-3) in early formation in the caudal fin anlage. Between 5.0 and $6.0 \mathrm{~mm} \mathrm{SL}$, some rays are visibly forming in the dorsal fin (Table 3 ).

Table 2. Morphological data for Anchoviella vaillanti larvae in the yolk-sac (YS), preflexion (PF), flexion (FL), postflexion (PO) stages and juvenile period (JV). All proportions are related to standard length, except for eye diameter, in relation to head length. Amplitude expressed in $\mathrm{mm}$, as minimum-maximum values $\pm \mathrm{sd}$ (Standard deviation).

\begin{tabular}{|c|c|c|c|c|c|c|c|c|c|c|}
\hline \multirow{3}{*}{ Measurements } & \multicolumn{8}{|c|}{ Larval stage } & \multirow{2}{*}{\multicolumn{2}{|c|}{$J V(n=30)$}} \\
\hline & \multicolumn{2}{|c|}{$\mathrm{YS}(\mathrm{n}=12)$} & \multicolumn{2}{|c|}{$\mathrm{PF}(\mathrm{n}=30)$} & \multicolumn{2}{|c|}{$\mathrm{FL}(\mathrm{n}=30)$} & \multicolumn{2}{|c|}{$\mathrm{PO}(\mathrm{n}=30)$} & & \\
\hline & $\begin{array}{c}\text { Amplitude } \\
(\text { min-max } \pm \text { sd })\end{array}$ & $\begin{array}{c}\text { Proportions } \\
(\%)\end{array}$ & $\begin{array}{c}\text { Amplitude } \\
(\text { min-max } \pm \text { sd })\end{array}$ & $\begin{array}{c}\text { Proportions } \\
(\%)\end{array}$ & $\begin{array}{c}\text { Amplitude } \\
(\text { min-max } \pm \text { sd })\end{array}$ & $\begin{array}{c}\text { Proportions } \\
(\%)\end{array}$ & $\begin{array}{c}\text { Amplitude } \\
(\text { min-max } \pm \text { sd) }\end{array}$ & $\begin{array}{c}\text { Proportions } \\
(\%)\end{array}$ & $\begin{array}{c}\text { Amplitude } \\
(\min -\max \pm \text { sd) }\end{array}$ & $\begin{array}{c}\text { Proportions } \\
(\%)\end{array}$ \\
\hline Standard length & $1.3-2.2 \pm 0.24$ & - & $2.7-6.9 \pm 1.09$ & - & $5.2-12.0 \pm 2.02$ & - & $9.5-19.3 \pm 2.17$ & - & $21.0-51.0 \pm 8.37$ & - \\
\hline Head length & $0.15-0.3 \pm 0.05$ & $10.0-14.3$ & $0.37-0.9 \pm 0.12$ & $7.9-14.8$ & $0.8-2.2 \pm 0.47$ & $10.4-19.1$ & $1.5-4.7 \pm 0.73$ & $15.4-26.1$ & $5.0-11.5 \pm 1.84$ & $20.6-26.6$ \\
\hline Body depth & - & - & $0.25-0.6 \pm 0.10$ & $6.3-10.0$ & $0.5-1.3 \pm 0.30$ & $7.8-12.0$ & $0.8-2.6 \pm 0.42$ & $8.4-15.8$ & $3.0-13.8 \pm 2.63$ & $14.0-27.1$ \\
\hline Head depth & $0.2-0.3 \pm 0.03$ & $9.1-14.3$ & $0.25-0.6 \pm 0.09$ & $5.7-10.0$ & $0.4-1.0 \pm 0.20$ & $6.5-9.5$ & $0.8-2.5 \pm 0.45$ & $6.7-15.2$ & $3.0-9.8 \pm 1.70$ & $13.3-19.2$ \\
\hline Eye diameter & 0.1 & 33.3 & $0.1-0.3 \pm 0.05$ & $16.7-40.0$ & $0.2-0.6 \pm 0.11$ & $17.6-40.0$ & $0.4-1.2 \pm 0.20$ & $18.8-30.0$ & $1.6-3.5 \pm 0.55$ & $25.4-40.0$ \\
\hline Preanal length & $1.3-1.5 \pm 0.09$ & $65.0-73.5$ & $2.2-5.2 \pm 0.79$ & $68.6-83.3$ & $4.0-8.7 \pm 1.50$ & $64.2-79.2$ & $6.8-12.7 \pm 0.93$ & $63.4-79.6$ & $14.0-32.0 \pm 5.29$ & $61.5-67.4$ \\
\hline Predorsal length & - & - & $3.0-4.5 \pm 0.48$ & $55.6-72.9$ & $3.6-7.2 \pm 1.13$ & $53.9-70.0$ & $5.6-10.6 \pm 0.93$ & $52.9-64.4$ & $11.5-28.0 \pm 4.46$ & $51.8-57.2$ \\
\hline Prepelvic length & - & - & - & - & - & - & $4.5-8.4 \pm 0.90$ & $37.8-46.9$ & $9.6-21.0 \pm 3.32$ & $40.7-47.2$ \\
\hline Prepectoral length & 0.3 & 13.6 & $0.4-1.1 \pm 0.18$ & $10.7-18.6$ & $0.9-2.5 \pm 0.50$ & $13.2-22.7$ & $1.6-5.3 \pm 0.77$ & $16.8-29.2$ & $5.6-12.4 \pm 1.99$ & $22.8-28.9$ \\
\hline
\end{tabular}


Table 3. Meristic data for preflexion (PF), flexion (FL), postflexion (PO) larvae and juveniles of Anchoviella vaillanti. Fins: pectoral (P), pelvic (PV), dorsal (D), anal (A) and caudal (C). nv - not visible. *in relation to precaudal vertebrae.

\begin{tabular}{|c|c|c|c|c|c|c|c|c|c|c|c|c|c|c|c|}
\hline \multirow{2}{*}{$\begin{array}{l}\overrightarrow{0} \\
\overrightarrow{0} \\
0 \\
0\end{array}$} & \multirow[b]{2}{*}{ Stage } & \multirow[b]{2}{*}{$\mathrm{SL}(\mathrm{mm})$} & \multicolumn{5}{|c|}{ Fin rays } & \multicolumn{3}{|c|}{ Myomeres } & \multicolumn{3}{|c|}{ Vertebrae } & \multicolumn{2}{|c|}{ Fin insertion* } \\
\hline & & & $\mathrm{P}$ & PV & $\mathrm{D}$ & $\mathrm{A}$ & $\mathrm{C}$ & preanal & postanal & total & precaudal & caudal & preural + urostyle & Dorsal & Anal \\
\hline \multirow{12}{*}{ 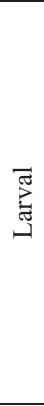 } & \multirow{3}{*}{$\mathrm{PF}$} & 3.7 & nv & $\mathrm{nv}$ & nv & nv & nv & nv & 25 & & nV & nv & nv & - & - \\
\hline & & 5.5 & nv & nv & 2 & nv & nv & 21 & 18 & 39 & nv & nv & nv & - & - \\
\hline & & 6.0 & nv & nv & 5 & nv & nv & 20 & 17 & 37 & nv & nv & nv & - & - \\
\hline & \multirow{6}{*}{ FL } & 7.0 & nv & nv & 8 & nv & nv & 20 & 16 & 36 & nv & nv & nv & - & - \\
\hline & & 8.0 & nv & nv & 9 & nv & $9+9$ & 21 & 15 & 36 & nv & nv & nv & - & - \\
\hline & & 8.5 & nv & nv & 11 & nv & $10+9$ & 21 & 14 & 35 & nv & nv & nv & - & - \\
\hline & & 10.8 & nv & nv & 11 & 21 & $10+10$ & 21 & 13 & 34 & 23 & 12 & $2+1$ & 18 & 24 \\
\hline & & 11.2 & nv & nv & 11 & 22 & $10+10$ & 21 & 13 & 34 & 23 & 12 & $2+1$ & 18 & 24 \\
\hline & & 12.0 & nv & nv & 12 & 21 & $10+10$ & 22 & 15 & 37 & 22 & 13 & $2+1$ & 17 & 23 \\
\hline & \multirow{3}{*}{ PO } & 13.4 & nv & 6 & 12 & 21 & $10+10$ & 21 & 13 & 34 & 21 & 14 & $2+1$ & 16 & 22 \\
\hline & & 14.4 & nv & 6 & 12 & 23 & $10+10$ & 22 & 15 & 37 & 21 & 14 & $2+1$ & 16 & 21 \\
\hline & & 18.8 & 12 & 7 & 12 & 24 & $11+11$ & 18 & nv & nv & 21 & 15 & $2+1$ & 15 & 22 \\
\hline \multirow{4}{*}{$\begin{array}{l}\stackrel{0}{\overrightarrow{0}} \\
\stackrel{0}{\Xi} \\
ٍ\end{array}$} & \multirow{4}{*}{$\mathrm{JV}$} & 20.7 & 12 & 7 & 14 & 24 & $11+11$ & 20 & 13 & 33 & 20 & 15 & $2+1$ & 14 & 21 \\
\hline & & 22.0 & 13 & 7 & 14 & 24 & $11+11$ & 21 & 15 & 36 & 21 & 15 & $2+1$ & 14 & 21 \\
\hline & & 27.0 & 12 & 7 & 14 & 23 & $11+11$ & 19 & 14 & 33 & 21 & 15 & $2+1$ & 14 & 22 \\
\hline & & 31.7 & 12 & 7 & 13 & 23 & $11+11$ & nv & nv & nv & 21 & 14 & $2+1$ & 14 & 22 \\
\hline
\end{tabular}

Flexion stage larvae (Fig. 1d-e) range from 5.2 to 12.0 $\mathrm{mm} \mathrm{SL}(\mathrm{n}=30)$. Body ranges from very elongate to elongate $(7.8-12.0 \% \mathrm{SL})$, head is small $(10.4-19.1 \% \mathrm{SL})$ and eye is small to large (17.6-40.0\% HL). Total myomeres range between 33 and 41 (18-25 preanal and 9-20 postanal; Table 3 ). This stage is characterized by notochord flexion and formation of hypurals and parhypural, which will support caudal fin rays. The finfold remnant in the gut region and isthmus pigmentation are still visible. Dorsal, anal and pectoral fin formation is evident as well as significant development of the head, with formation of gill arches, filaments and rays; opercle and preopercle, and mouth bones and nasal pores. In $7.5 \mathrm{~mm}$ SL larvae, the caudal fin has visible hypural, parhypural and epural bones, and dorsal, anal and caudal rays begin to form (Table 3, Fig. 1). Pterygiophore number in dorsal fin ranged from 9 to 10 in larvae with SL between 7.5 and $8.5 \mathrm{~mm}$ and those with SL $>8.0 \mathrm{~mm}$ have more than 20 pterygiophores in the anal fin, with visible rays, while the pectoral fins have no rays yet. From $10.3 \mathrm{~mm}$ SL onwards, pigments begin to appear in the caudal fin extremities and two pigments posterior to anal fin. At $11.2 \mathrm{~mm} \mathrm{SL}$, the definitive number of anal fin rays is reached (Table 3); the two pigments on its base are no longer visible, but a chromatophore in the median base of the caudal fin and another punctiform chromatophore on base of the pectoral fin are visible. The definitive number of dorsal fin rays is reached at $12.0 \mathrm{~mm} \mathrm{SL}$.

In postflexion stage larvae (Fig. 1f-g), standard length ranges from 9.5 to $19.3 \mathrm{~mm}(\mathrm{n}=30)$. Total myomere number ranges from 34 to 38 (18-25 preanal and 13-15 postanal). Body is very elongate to elongate $(8.4-15.8 \% \mathrm{SL})$, head is small to moderate $(15.4-26.1 \% \mathrm{SL})$ and eye is small to moderate (18.8-30.0\% HL; Table 2). This stage is characterized by pelvic fin insertion, complete ray formation and the beginning of squamation. The most significant changes, however, are related to body proportions, as the increase in body depth is greater than length, which give early juveniles a more fusiform aspect than the previous vermiform shape of the late larvae. The swimbladder is clearly visible, with dendritic chromatophores above it. Punctiform chromatophores appear on the back of the larvae, first near caudal region and afterwards developing on base of the dorsal fin and in the predorsal region, subsequently substituted by dendritic chromatophores. Pigmentation on the caudal fin is more intense. Chromatophores previously visible on the isthmus, pectoral fin base and central base of the caudal fin are still evident. Pectoral fin rays appear in definitive number in $18.8 \mathrm{~mm}$ SL larvae, which also have the definitive number of pelvic and caudal fin rays (Table 3 ).

Individuals analyzed in the juvenile period (Fig. 1h-i) have 21 to $51 \mathrm{~mm} \mathrm{SL}(\mathrm{n}=30)$. Body ranges from elongate to moderate $(14.0-27.1 \% \mathrm{SL})$, head is moderate $(20.6-26.6 \%$ $\mathrm{SL}$ ) and eye is moderate to large (25.4-40.0\% HL) (Table 2). Individuals that still have visible myomeres have a total number ranging from 33 to 35 (18-22 preanal and 13-15 postanal). Throughout the juvenile period, which begins with scale formation, no significant morphological changes are evident, as juveniles resemble adults, except for squamation and body pigmentation. Punctiform and dendritic chromatophores intensify in the nuke and their pigmentation increases on base of the anal fin and beyond. Dorsal region pigmentation is similar to the previous stage; the base of the caudal fin is also pigmented; the chromatophore on its base is still visible and larger individuals may exhibit dendritic and punctiform chromatophores sparsely distributed along sides of the body.

Body relations and respective proportions in different developmental stages are detailed in Table 2. Prefin lengths in relation to SL ranged from 61.5 to $83.3 \%$ for PAL; 51.8 to $72.9 \%$ for PDL; 10.7 to $29.2 \%$ for PPL and 37.8 to $47.2 \%$ for 
a

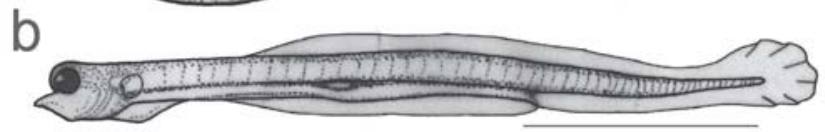

C
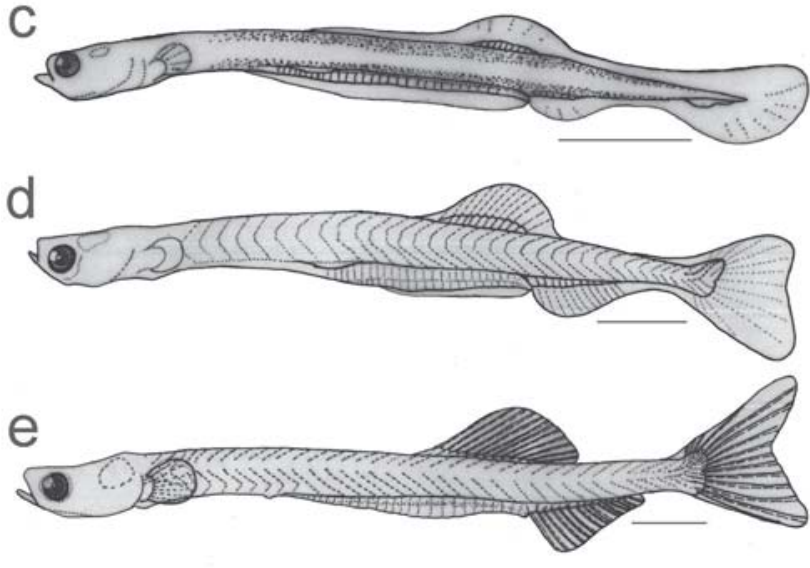

f

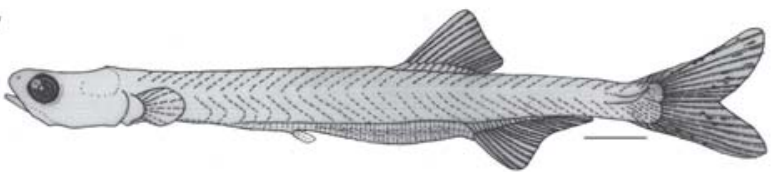

g

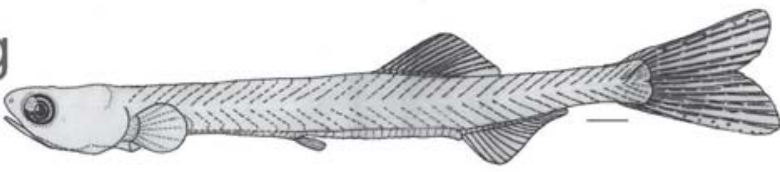

h
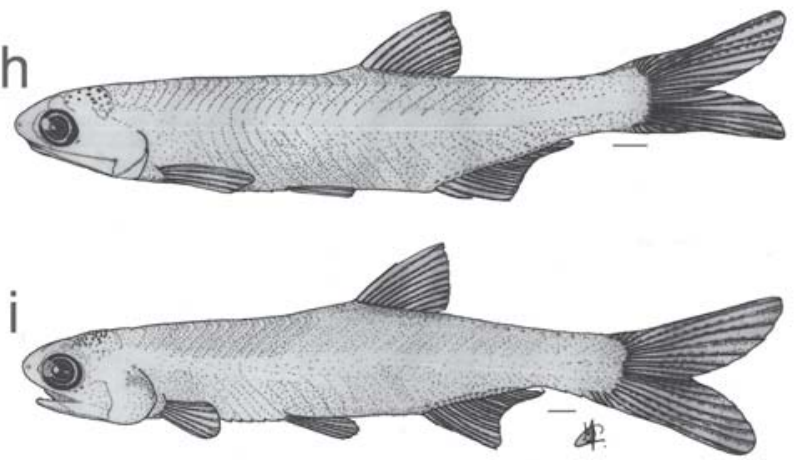

Fig. 1. Larva and juvenile Anchoviella vaillanti: $1.7 \mathrm{~mm}$ yolk-sac larva (a), $3.2 \mathrm{~mm}$ (b) and $5.5 \mathrm{~mm}$ (c) preflexion larvae, $7.6 \mathrm{~mm}(\mathbf{d})$ and $10.7 \mathrm{~mm}$ (e) flexion larvae, $13.8 \mathrm{~mm}(\mathbf{f})$ and 16.0 $\mathrm{mm}(\mathbf{g})$ postflexion larvae, and $25.5 \mathrm{~mm}(\mathbf{h})$ and $30.0 \mathrm{~mm}(\mathbf{i})$ early juveniles. Scale bar $=1 \mathrm{~mm}$.
PPVL. Head length ranged from 7.9 to $26.6 \%$; HD from 5.7 to $19.2 \%$; $\mathrm{BD}$ from 6.3 to $27.1 \%$; and $\mathrm{ED}$ from 16.7 to $40.0 \%$ HL. Mean values of the relations PDL/SL and PAL/SL differed significantly $(p<0.0001)$ among developmental stages (Fig. 2a,b), with an evident reduction from preflexion larvae to juveniles, and tend to stabilize in individuals larger than $20.0 \mathrm{~mm}$ SL (Fig. 2a,b), reaching a mean value of $64.4 \pm 1.6 \%$ SL for PAL and $54.7 \pm 1.4 \%$ SL for PDL (Fig. 2c). Juveniles differed from postflexion larvae in the mean values of $\mathrm{PDL} / \mathrm{SL}(\mathrm{MS}=9.6876 ; \mathrm{df}=100)$ and $\mathrm{PAL} / \mathrm{SL}(\mathrm{MS}$ $=9.1652 ; \mathrm{df}=100)$ relations, as well as from previous larval stages. Such difference is related to the change in insertion position of dorsal and anal fins in relation to vertebra count during metamorphosis from larval to juvenile period (see below).

Total vertebra number in Anchoviella vaillanti ranges from 36 to 39 and the myomere number ranges from 31 to 45. Dorsal fin insertion varies between the $14^{\text {th }}$ and $18^{\text {th }}$ precaudal vertebra and anal fin insertion varies between $21^{\text {st }}$ and $24^{\text {th }}$ precaudal vertebra. Between the flexion stage and juvenile period, dorsal and anal fin insertion points move forward: dorsal from the $17^{\text {th }}-18^{\text {th }}$ to $14^{\text {th }}$ vertebra and anal from $23^{\text {rd }}-24^{\text {th }}$ to $21^{\text {st }}-22^{\text {nd }}$ vertebra (Table 3 ).

The sequence of first fin ray formation in A. vaillanti is $\mathrm{D}, \mathrm{C}, \mathrm{A}, \mathrm{V}$ and $\mathrm{P}$. The definitive number of rays, however, is attained in the following order: $\mathrm{D}$ and $\mathrm{A}$ in the flexion stage and $\mathrm{P}, \mathrm{V}$ and $\mathrm{C}$ in the postflexion stage (Table 3 ).

\section{Discussion}

Similarly to Anchoviella vaillanti, engraulid larvae are poorly pigmented. The dorsal fin has fewer rays than the anal fin, the base of which is initially shorter than the dorsal fin, the pelvic fin appears ahead of the swimbladder and, like many species other than $A$. vaillanti, the pelvic fin may have some inner pigmentation (Leis \& Trnski, 1989). The body is very elongate to almost cylindrical at first and becomes moderately compressed in the flexion stage. The gut is straight and has 39 to 46 myomeres, the preanal and postanal proportion of which varies depending on dorsal and anal fin migration (Leis \& Trnski, 1989). The sequence of fin ray development recorded for A. vaillanti (D \& A, C, $\mathrm{V}, \mathrm{P}$ ) is similar to that of other engraulids (Farooqi et al., 2006).

The most commonly used character for the identification of clupeiform larvae is the total myomere and vertebra count, together with color pattern when the vertebra count overlaps among similar species (McGowan \& Berry, 1984). The total myomere count in Anchoviella vaillanti does not coincide with the vertebra number, which may be attributed to the fact that the preanal myomere number does not coincide with precaudal vertebrae, mainly due to morphological changes during the metamorphosis from larva to juvenile (McGowan \& Berry, 1984). 

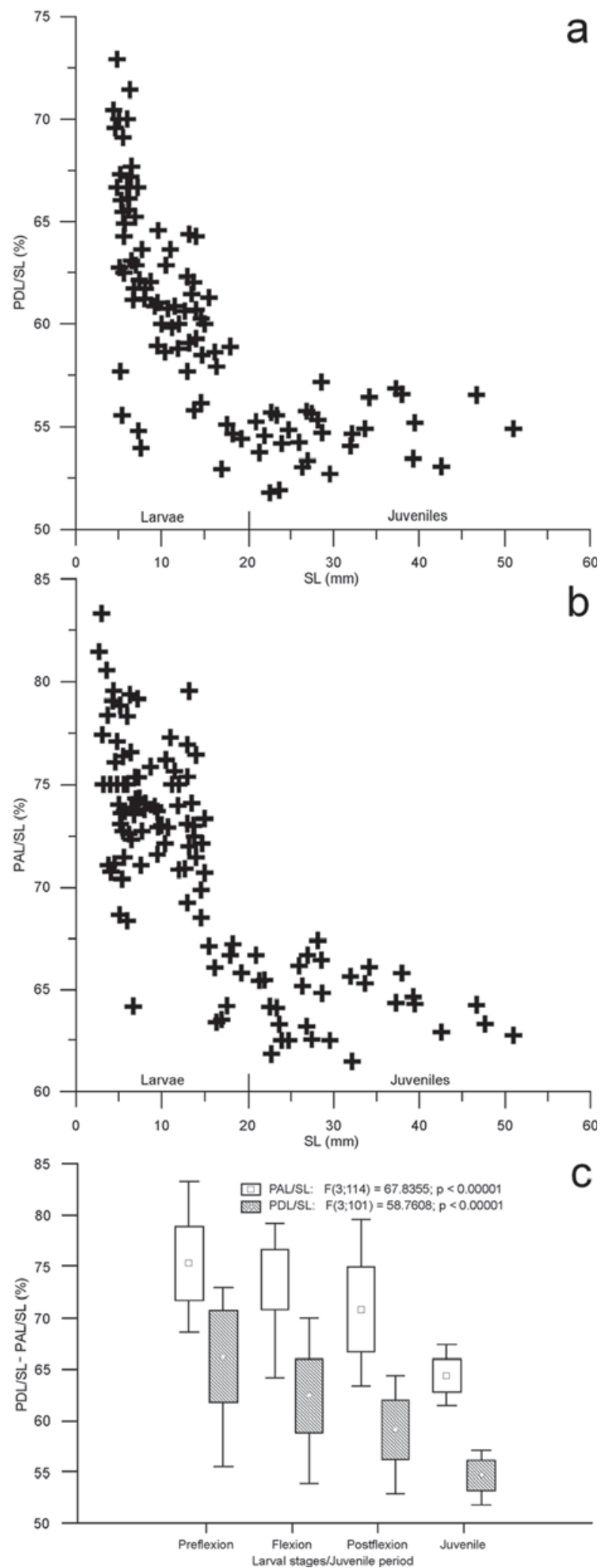

Fig. 2. Variation of (a) predorsal (PDL) and (b) preanal (PAL) lengths as percentage of standard length (SL) of larvae and juveniles of Anchoviella vaillanti, and (c) mean values for PDL/SL and PAL/SL for larval stages (preflexion, flexion and postflexion) and juveniles. Mean values; box: mean \pm standard deviation, whisker: minimum-maximum values.
One of the features leading to the differentiation of Clupeidae and Engraulidae larvae is the relative position of dorsal and anal fins; in engraulids, the anal fin is inserted in a more posterior position in relation to dorsal fin. However, larvae identification is more difficult in the early stages between yolk-sac absorption and formation of the dorsal fin and the myomere count is more useful for their discrimination (McGowan \& Berry, 1984; Farooqi et al., 2006). Engraulids differentiate from other clupeiforms in their lower, wider mouth and more prominent snout (Kullander \& Ferraris, 2003), which is only evident in juveniles and adults.

The change in the position of dorsal and anal fin insertions in clupeids and engraulids is common during transition from the larval to juvenile period (Cohen, 1984), in which the number of dorsal and anal fin rays stabilizes at an average size of approximately $20 \mathrm{~mm}$ SL (McGowan \& Berry, 1984), as also observed in Anchoviella vaillanti. For instance, Sardinella aurita undergoes a reduction in the number of preanal and predorsal myomeres during development, while the number of postanal myomeres increases. An advance of ten myomeres in the insertion point of dorsal fin in relation to the anal fin has been recorded for Saraineps sagax (Ahlstrom, 1968), eight myomeres in Harengula jaguana (Houde et al., 1974), four in Sardinella brasiliensis (Matsuura, 1975) and five in Pellona flavipinnis (Severi \& Verani, 2006). In A. vaillanti, dorsal fin insertion moved four vertebrae in relation to anal fin.

As the only freshwater clupeiform species in the São Francisco River basin, larvae of Anchoviella vaillanti are easily identified and discriminated from other orders using the typical characteristics of the order. However, in the lower stretches of São Francisco River, downriver from the Xingó hydroelectric plant, the engraulid A. lepidentostole (Fowler), which is a euryhaline marine fish that may occasionally swim upstream to totally freshwater stretches, is also present. Although its reproduction and initial development predominantly occurs in estuarine areas, both species may coexist in these lower stretches. Early larval developmental stages of $A$. lepidentostole have not been described so far (see Richards, 2006), and their larvae may not be properly differentiated from those of $A$. vaillanti. However, late larval stages and juveniles of the former may be distinguished from those of $A$. vaillanti by its higher number of dorsal fin rays (15 or 16 vs. 12 or 13 in A. vaillanti), higher total vertebra number (40vs. 37 to 40 ) and shorter prepectoral length (14 to 16 vs. 22.8 to $28.9 \% \mathrm{SL}$ ).

\section{Acknowledgements}

The authors are grateful to the Companhia Hidro Elétrica do São Francisco (CHESF) and the Fundação Apolônio Salles de Desenvolvimento Educacional (FADURPE) for financial support for the research project and the graduate scholarship provided to Anailza C. G. Silva. The interns at 
the Ichthyology Laboratory helped in the field and sample sorting at the laboratory.

\section{Literature Cited}

Ahlstrom, E. H. 1968. Review of "Development of fishes of the Chesapeake Bay region, an atlas of egg, larval and juvenile stages, Part I". Copeia, 1968: 648-651.

Araújo-Lima, C. A. R. M. 1985. Aspectos biológicos de peixes amazônicos. V. Desenvolvimento larval do jaraqui-escama grossa, Semaprochilodus insignis (Characiformes, Pisces) da Amazônia Central. Revista Brasileira de Biologia, 45: 423 431.

Araújo-Lima, C. A. R. M. 1991. A larva da branquinha comum, Potamorhina latior (Curimatidae, Pisces) da Amazônia Central. Revista Brasileira de Biologia, 51: 45-56.

Araújo-Lima, C. A. R. M., A. L. Kirovsky \& A. G. Marca. 1993. As larvas dos pacus, Mylossoma spp. (Teleostei; Characidae), da Amazônia Central. Revista Brasileira de Biologia, 53: 591600 .

Bialetzki, A., P. V. Sanches, G. Baumgartner \& K. Nakatani. 1998. Caracterização morfológica e distribuição temporal de larvas e juvenis de Apareiodon affinis (Steindachner 1879) (Osteichthyes, Parodontidae) no alto do rio Paraná (PR). Revista Brasileira de Zoologia, 15: 1037-1047.

Bialetzki, A., G. Baumgartner, P. V. Sanches, A. V. Galuch, M. A. Luvisuto, K. Nakatani, M. Cavicchioli-Makrakis \& M. E. E. Borges. 2001. Caracterização do desenvolvimento inicial de Auchenipterus osteomystax (Osteichthyes, Auchenipteridae) da bacia do rio Paraná, Brasil. Acta Scientiarum, Biological Sciences, 23: 377-382.

Bialetzki, A., K. Nakatani, P. V. Sanches, G. Baumgartner, M. C.-Makrakis \& T. L. Taguti. 2008. Desenvolvimento inicial de Hoplias aff. malabaricus (Bloch, 1794) (Osteichthyes, Erythrinidae) da planície alagável do alto rio Paraná, Brasil. Acta Scientiarum, Biological Sciences, 30: 141-149.

Cavicchioli, M., K. Nakatani \& O. K. Shibatta. 1997. Morphometric variation of larvae and juveniles of the piranhas Serrasalmus spilopleura and S. marginatus (Characidae: Serrasalminae) of the Paraná basin, Brazil. Ichthyological Exploration of Freshwaters, 8: 97-106.

Cohen, D. M. 1984. Ontogeny, systematics, and phylogeny. Pp. 108-126. In: Moser, H. G., W. J. Richards, D. M. Cohen, M. P. Fahay, A. W. Kendall Jr. \& D. S. L. Richardson (Eds.). Ontogeny and systematics of fishes. Lawrence, Allen Press, American Society of Ichthyologists and Herpetologists Spec. Publ. 1. 760p.

Dingerkus, G. \& L. D. Uhler. 1977. Enzyme clearing of alcian blue stained whole small vertebrates for demonstration of cartilage. Stain Technology, 52: 229-232.

Farooqi, T., J. G. Ditty \& R. F. Shaw. 2006. Engraulidae: Anchovies. Pp. 101-127. In: Richards, W. J. (Ed.). Early stages of Atlantic fishes: an identification guide for western central North Atlantic. Boca Raton, CRC Press, 2640p.

Godinho, H. P., J. E. Santos \& Y. Sato. 2003. Ontogênese larval de cinco espécies de peixes do São Francisco. Pp. 133-148. In: Godinho H. P. \& A. L. Godinho (Eds.). Águas, peixes e pescadores do São Francisco das Minas Gerais. Belo Horizonte, CNPq/PADCT, Editora PUC Minas, 458p.

Houde, E. D., W. J. E. Richards \& V. P. Saksena. 1974
Description of eggs and larvae of scaled sardine, Harengula jaguana. Fish Bulletin, 72: 1106-1122.

Kullander S. O. \& C. J. Ferraris Jr. 2003. Family Engraulididae (anchovies). Pp. 39-45. In: Reis, R. E., S. O. Kullander \& C.J. Ferraris Jr. (Eds.). Check list of the freshwater fishes of South and Central America. Porto Alegre, Edipucrs, 729p.

Leis, J. M. \& T. Trnski. 1989. The larvae of Indo-Pacific Shorefishes. Honolulu, University of Hawaii, 371p.

Matsuura, Y. 1975. A study of the life history of Brazilian sardine, Sardinella brasiliensis. III. Development of sardine larvae. Boletim do Instituto Oceanográfico, 24: 17-29.

McGowan, M. F. \& F. H. Berry. 1984. Clupeiformes: development and relationships. Pp. 108-126. In: Moser, H. G., W. J. Richards, D. M. Cohen, M. P. Fahay, A. W. Kendall Jr., D. S. L. Richardson (Eds.). Ontogeny and systematics of fishes. Lawrence, Allen Press, American Society of Ichthyologists and Herpetologists Spec. Publ. 1, 760p.

Menezes, N. A. \& M. C. C. de Pinna. 2000. A new species of Pristigaster, with comments on the genus and redescription of $P$. cayana (Teleostei: Clupeomorpha: Pristigasteridae). Proceedings of the Biological Society of Washington, 113: 238-248.

Nakatani, K., G. Baumgartner \& M. S. T. Baumgartner. 1997. Larval development of Plagioscion squamosissimus (Heckel) (Perciformes Sciaenidae) of Itaipu reservoir (Paraná River, Brazil). Revista Brasileira de Zoologia, 14: 35-44.

Nakatani, K., A. A. Agostinho, G. Baumgartner, A. Bialetzki, P. V. Sanches, M. C. Makrakis \& C. S. Pavanelli. 2001. Ovos e larvas de peixes de água doce: desenvolvimento e manual de identificação. Maringá, Eduem, 378p.

Oliveira, E. C., A. Bialetzki \& L. F. Assakawa. 2008. Morphological development of Hypophthalmus fimbriatus and $H$. marginatus post-yolk-sac (Siluriformes: Pimelodidae). Zootaxa, 1707: 37-48.

Peret, A. M. 2004. Dinâmica da alimentação de peixes piscívoros da Represa de Três Marias, MG. Unpublished M.Sc. Dissertation. Universidade Federal de São Carlos, São Carlos. 60p. Available at: http://www.sfrancisco.bio.br/ publicacoes.html/Peret\%20AM001.pdf. Accessed December 8,2009

Pompeu, O. S. \& H. P. Godinho. 2003. Dieta e estrutura trófica das comunidades de peixes de três lagoas marginais do médio São Francisco. Pp. 183-194. In: Godinho H. P. \& A. L. Godinho (Orgs.). Águas, peixes e pescadores do São Francisco das Minas Gerais. Belo Horizonte, CNPq/PADCT, Editora PUC Minas, 458p.

Reis, R. E., S. O. Kullander \& C. J. Ferraris Jr. (Eds.). 2003. Check list of the freshwater fishes of South and Central America. Porto Alegre, Edipucrs, 742p.

Richards, W. J. (Ed.). 2006. Early stages of Atlantic fishes: an identification guide for western central North Atlantic. Boca Raton, CRC Press, 2640p.

Rocha, A. A. F. 2009. Composição e sobreposição alimentar de Acestrorhynchus britskii e A. lacustris (Characiformes: Acestrorhynchidae) do reservatório de Sobradinho, rio São Francisco (BA). Unpublished MSc. Dissertation. Universidade Federal Rural de Pernambuco, Recife. 47p. Available from: http://www.pgpa.ufrpe.br/Trabalhos/2009/ T2009aafr.pdf (accessed 8 December 2009).

Sampaio, K. H. 2006. Superfície ovocitária e desenvolvimento inicial de quatro espécies de peixes de interesse comercial da bacia do rio São Francisco. Unpublished M.Sc. Dissertation, 
Universidade Federal de Minas Gerais, Belo Horizonte, 53p. Sanches, P. V., K. Nakatani \& A. Bialetzki. 1999. Morphological description of development stages in Parauchenipterus galeatus (Linnaeus, 1766) (Siluriformes, Auchenipteridae) in the upper Paraná River floodplain, Paraná, Brazil. Revista Brasileira de Biologia, 59: 1-10.

Sanches, P. V., G. Baumgartner, A. Bialetzki, M. R. Suiberto, F. D. C. Gomes, K. Nakatani \& M. D. C. Barbosa. 2001. Caracterização do desenvolvimento inicial de Leporinus friderici (Osteichthyes, Anostomidae) da bacia do rio Paraná. Acta Scientiarum, Biological Sciences, 23: 383-389.

Severi, W. \& N. F. Verani. 2006. Morphological development of Pellona flavipinnis post-yolk-sac larvae and juveniles (Clupeiformes: Pristigasteridae). Zootaxa, 1126: 21-33.

Sousa, W. T. Z. \& W. Severi. 2002. Desenvolvimento inicial de larvas de Rhaphiodon vulpinus Agassiz (Characiformes, Cynodontidae). Revista Brasileira de Zoologia, 19: 85-94.

Statsoft. 2008. Statistica (data analysis software system), version 8. Tulsa, Statsoft Inc. www.statsoft.com.

Steindachner, F. 1908. Über zwei neue Fischarten aus dem Stromgebiete des Rio San Francisco. Anzeiger der Akademie der Wissenshaften in Wien, 45: 191-194.

Whitehead, P. J. P. 1970. The clupeoid fishes described by Steindachner. Bulletin of the British Museum of Natural History (Zoology), 20: 1-46.

Whitehead, P. J. P. 1973. The clupeoid fishes of the Guianas. Bulletin of the British Museum of Natural History (Zoology), Supplement 5: 1-227.

Whitehead, P. J. P. 1985. FAO species catalogue. Vol. 7. Clupeoid fishes of the world (Suborder Clupeoidei). An annotated and illustrated catalogue of the herrings, sardines, pilchards, sparts, anchovies and wolfherrings. Part 1 - Chirocentridae, Clupeidae and Pristigasteridae. FAO Fisheries Synopsis 125, 7(Pt. 1): 1-303.

Whitehead, P. J. P., G. J. Nelson \& T. Wongratana. 1988. FAO species catalogue. Vol. 7. Clupeoid fishes of the world (Suborder Clupeoidei). An annotated and illustrated catalogue of the herrings, sardines, pilchards, sparts, anchovies and wolfherrings. Part 2. Engraulididae. FAO Fisheries Synopsis 125, 7(Pt. 2): 305-579.

Accepted September 30, 2010

Published December 16, 2010 